\title{
BUILT ENVIRONMENT AND ITS IMPACT ON CRIMES RELATED TO WOMEN IN NCT OF DELHI: A PILOT SURVEY
}

\author{
Charu Nangia* \\ Research Scholar, Amity School of Architecture and Planning, Amity University, \\ Noida, India \\ Dr Devendra Pratap Singh \\ Dean, Amity School of Architecture and Planning, Amity University, Noida, India \\ Dr Sabir Ali \\ Professor, Amity School of Architecture and Planning, Amity University, Noida, India \\ *Corresponding Author E-mail:charu.nangia@hotmail.com
}

\begin{abstract}
The purpose of this paper is to critically analyze the impact of the built environment on crimes related to women in the National Capital Territory (NCT) of Delhi through a pilot study with minimum responses. The objective of the study was to examine the built environment attributes affecting the crimes related to women in NCT of Delhi and to compare the very high crime rate areas vs very low crime rate areas as per the Delhi Police crime statistics to know the basic root cause of the incidence of crimes. The methodology adopted for the study is a structured questionnaire survey and statistical data analysis. The SPSS 23 statistical package is used for this study. A total of four wards (neighbour-hoods) were selected for the present study comprising two wards from very high crime and two wards from very low crime rate districts of Delhi and a total of 80 responses were collected for this pilot study. The findings of the study also validate the perception of the residents which confirm that the lack of desirable built environment facilities lead to high crime rate in the selected wards i.e. IP Extension and MayurVihar-II, whereas the availability of adequate desirable built environment facilities precedent of low rate of crime committed against women in the selected wards i.e. Pitam Pura and Shalimar Bagh. The future scope of the study is to undertake a comprehensive study of all the attributes of built environment impacting the crime rates against women in NCT of Delhi on the basis of structured questionnaire survey (the same questionnaire has been used for the pilot survey for 80 numbers of respondents) with a sample size of 450-500 to reduce the chances of error and to generalize the findings of the study.
\end{abstract}

Key words: CPTED; Built Environment; Crime against Women; NCT-Delhi; Cities. 
Cite this Article: Charu Nangia, Dr Devendra Pratap Singh and Dr Sabir Ali, Built Environment and its Impact on Crimes Related to Women in NCT of Delhi: A Pilot Survey, International Journal of Advanced Research in Engineering and Technology, 10 (3), 2019, pp 57-68.

http://iaeme.com/Home/issue/IJARET?Volume $=10 \&$ Issue $=3$

\section{INTRODUCTION AND BACKGROUND}

CRIME is an unlawful act present in all the societies since all the ages. Only the type, dimension, the name varies from place to place. The concern to crime and fear of crime is definitely a prime issue in the postmodern society with a high rate of urbanization. The word crime is from the Latin word "Crimen"- means accusation [1]-[6]. In criminology, crime/violence against women is the most persistent, yet most under-recognized one, in the world. For over decades, a crime against women drew more attention as serious and adverse crimes than others.

In terms of crime prevention methods, there are various approaches that can be adopted, namely: (i) from the aspects of the legal system or the enforcement of the policing system monitoring [5], [7], (ii) social approach [8]-[10], (iii) offender approach and (iv) physical environment approach [1], [2], [11], [12]. Within all these approaches, the physical environment is considered to be more important than the social environment. This is due to the fact that physical environmental design involves constant elements that may be modified through planning and design in order to reduce the opportunities for crime, elements such as physical layout, housing typology and the outlook of the surrounding environment are the main focal criteria for the occurrences of crime[13]-[16].

\section{ORIGINS, HISTORY, AND DEVELOPMENT OF CPTED}

The concept and design of CPTED could be traced back to the long history of human settlements. This includes the development of forts and castles, which used moats, walls, landscaping, and bridges to control access. Significantly, Edward, I enacted the Statute of Winchester in 1285 to remove areas of concealment provided by ditches and vegetation along highways. Landowners were responsible for removing vegetation and ditches and were also held liable for crimes that took place due to their negligence in not removing concealment opportunities. The highway from one merchant town to another shall be cleared so that no cover for malefactors should be allowed for a width of two hundred feet on either side; landlords who do not affect this clearance will be answerable for robberies committed in consequence of their default, and in case of murder they will be on the King's mercy [7], [10].

Jane Jacobs's 'The Death and Life of Great American Cities' (1961) did much to challenge contemporary ideas about planning. It identified safety and security as significant elements of a well-functioning city, arguing the bedrock attribute of a successful city district is that a person must feel personally safe and secure on the street, must have three main qualities:

- There must be a clear demarcation between what public space is and what private space is.

- There must be eyes upon the street; eyes belonging to those we might call the natural proprietors of the street. The buildings on a street equipped to handle strangers. Must be oriented to the street.

- The sidewalk must have users on it fairly continuously, both to add to the number of effective eyes on the street and to induce the people in buildings along the street to watch the sidewalks in sufficient numbers"' [17], [18]. 
Jeffery (1971) suggested that the social causes of crime had been overstated and the biological and environmental determinants of crime required inspection. He further suggested that the causes of crime are more multidisciplinary and holistic approach is needed to analyze the psychological, social, political, behavioural, and biological explanations [3]-[5], [7]-[9], [19], [20].

\subsection{Crime Prevention through Environmental Design}

Crime prevention through environmental design (CPTED) is firstly introduced by Crowe (2000) aligned with the notion of Newman's Defensible Space. Jeffery was the first to use this phrase as the title for his book. Jeffery's theory was based on the idea that the current crime control policies being used were ineffective. He argued that the best way to reduce crime was to directly organize environmental conditions prior to the punishment for an offence.

\subsection{Crime against Women (CAW) or Women's Fear of Attack and the Built Environment}

The relationship between community safety and built environments has been a popular focus in studies of crime in the environmental disciplines [3], [10], [67], [15], [19]-[22], [26], [28], [49]. The notion that fear of crime can be 'designed out', or at least its worst effects moderated by changing built environments has underpinned many policy recommendations and initiatives [8], [9], [25], [38], [40].

\subsection{Women's Safety and the Built Environment}

Among the strongest critiques of mainstream fear of crime theory have been those of feminist criminologists, particularly [16], [25], [40] who has high- lighted the socio-political constitution of fear of crime, in particular, its gendered nature. Elsewhere that feminists concerned with women's safety in relation to practical planning issues were amongst the earliest and strongest supporters of 'designing out fear'. Women's fear of attack within built environments has received special attention both from geographers, at least in the UK and North America where women's safety has been on political agendas for some time. In Finland safety has not been a significant goal planning until recently and the objective of taking better account of women's concerns is just emerging. Elsewhere in Western Europe and in North America, many city authorities have integrated women's concerns into measures aimed at reducing fear, in particular, environments [2], [16], [25], [26]. The feminist perspective on environmental design sets women's unsafety firmly in a socio-political framework of patriarchal relations; relating fear to tangible risks and to women's broader social vulnerability as well as highlighting the man-made nature o, particularly designed environments. Given recent developments in feminist geographical and criminological theories, this strength of support can be questioned on a number of grounds. Delhi recorded higher rates of violent crimes, as compared to other cities. According to the Delhi Human Resource Development report 2013, there is a sharp rise in crimes against property percentage from 38.2 to 48.5 from the year 2004-06 to 2010-12 in NCT of Delhi. It is also evident from the statistical records furnished in Delhi Human Resource Development report 2013, that the percentage of crime against women has raised from $6.7 \%$ to $9.5 \%$ of the total crime from the year 2004-06 to the year 2010-12. Composition of crimes percentage in Delhi during the period 2004-06 and 2010-12 shown below (figure-1) 


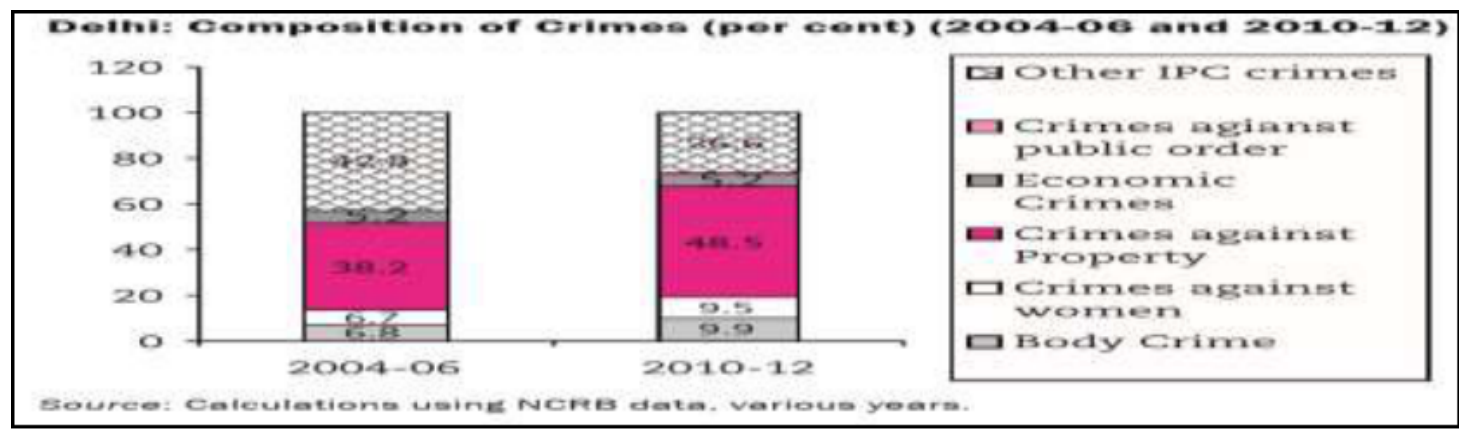

Figure- 1 Composition of Crimes (percentage), 2004-06 \& 2010-12 in Delhi, DHRD report 2013

Researchers have observed that the demographic profile of an area is correlated with the levels of crimes rate. The areas with higher densities witness more crimes (Patrick G. Donnelly, 1988). According to Donnelly, there is also a direct relation of social variables with the crimes, community with low income and education level observe more crime rate. Crimes are more prevailing in the areas where people are young, belong to a minority group and highly mobile, crime incidence are less in the areas where residents own their houses and are living for a longer period (Skogan \& Maxfield, 1981). The scholars have observed that the crime and fear of being victimized are more prevalent among people who are isolated and vulnerable (Braungart \& Hoyer, 1980). It is concluded that elderly, women and people who live alone are more scared of crime than others (Donnelly, 1988).

\section{RESEARCH METHODOLOGY}

The methodology adopted for the study is to undertake a Household (HH) survey through a structured questionnaire to understand people's perception about the crime rate and the factors of the built environment supporting crime incidence in their respective wards. The respondents were selected on a random basis. The SPSS 23 statistical package is used for statistical analysis in this study. A total of four wards were selected for the study as wards are recognized to be the neighbourhoods with legitimate delineated administrative boundary within the city. Two wards from each of the two districts of Delhi attaining very high and very low crime rate against women respectively were identified on the basis of higher crime density (number of crimes/sq.km.) pattern taking crime data from NCRB reports from the year 2011-15 and Census 2011 in consideration. The wards namely Mayur Vihar-II and I.P. Extension from East (E) district and Pitam Pura and Shalimar Bagh from North -West (NW) of Delhi were selected due to accommodating the highest number of households (HH) in the respective district with an adequate level of public open spaces. A total of 80 responses were collected for this pilot study taking 20 responses from each ward covering all strata of people. To collect data, the Likert scale of 1-7 has been used. The data has been collected by the scholar from the respondents on hard copy sheets assembled in both the languages i.e. in Hindi, and English for providing a good understanding of the questions and the traits of the built environment on crime related to Women in NCT of Delhi.

It is illustrated in Chart 1 the entire study has been divided into seven heads including problem identification, formulation of the research question, literature review, research plan, data collection, data analysis and conclusions. The research question of the study has been formulated as - 'Do the factors of built environment impact the crimes related to women in urban neighbourhoods?' The objectives of the study were set in order to provide direction of study for achievingthe goal. A detailed literature review has been carried out through secondary sources to understand the knowledge gap and for identifying the dependent and independent variables of the study leading to the formulation of the survey questionnaire. A 
pilot survey was conducted for the validation and reliability of the questionnaire. The data collected was analyzed to draw the conclusions.

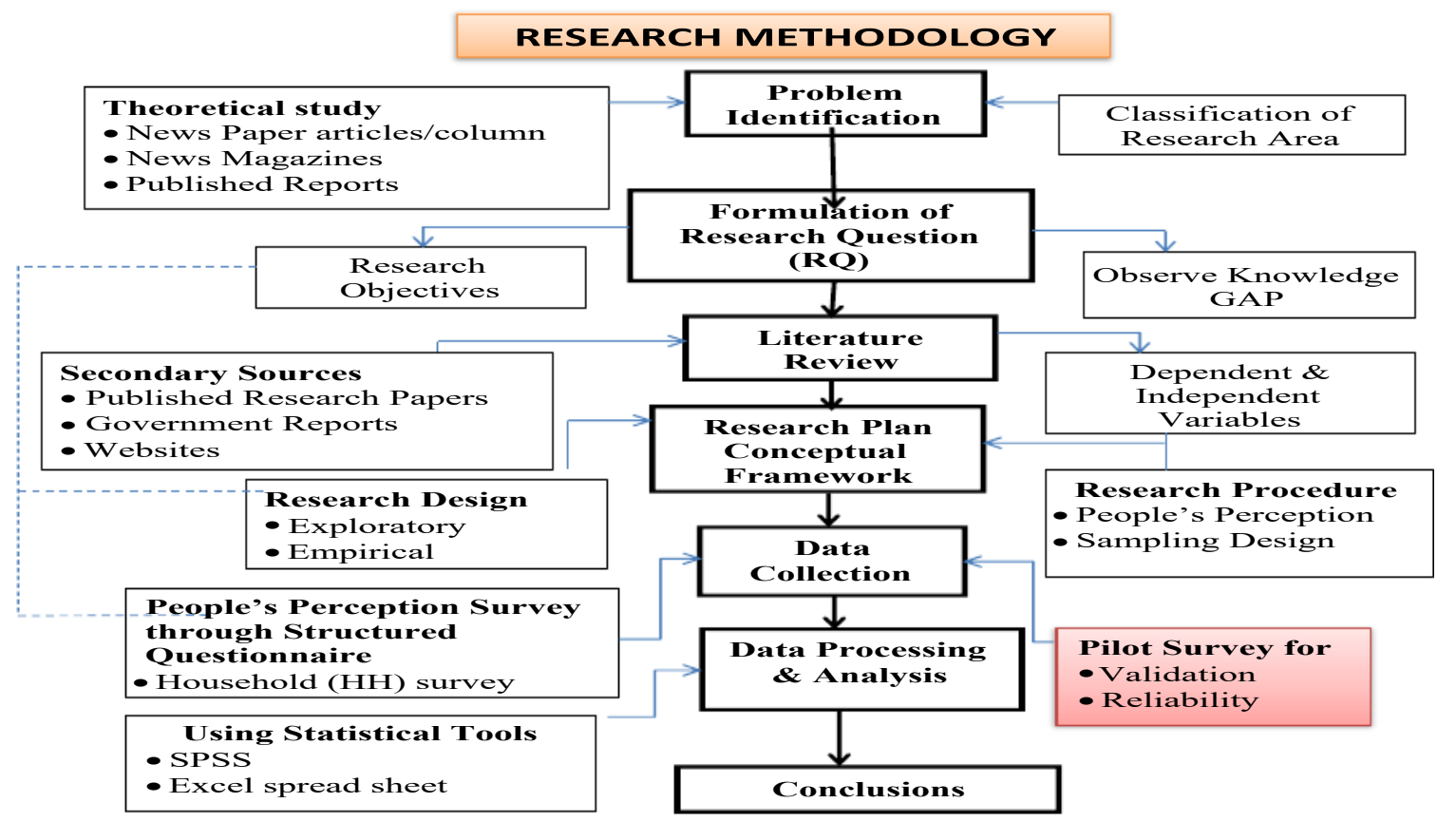

Chart 1 Research Methodology Flow Chart

\section{DATA ANALYSIS}

\subsection{Respondents Profile}

The collected data were compiled into an excel spreadsheet for further analysis. The respondents profile analyzed in this study are as follows (figure 2-4):

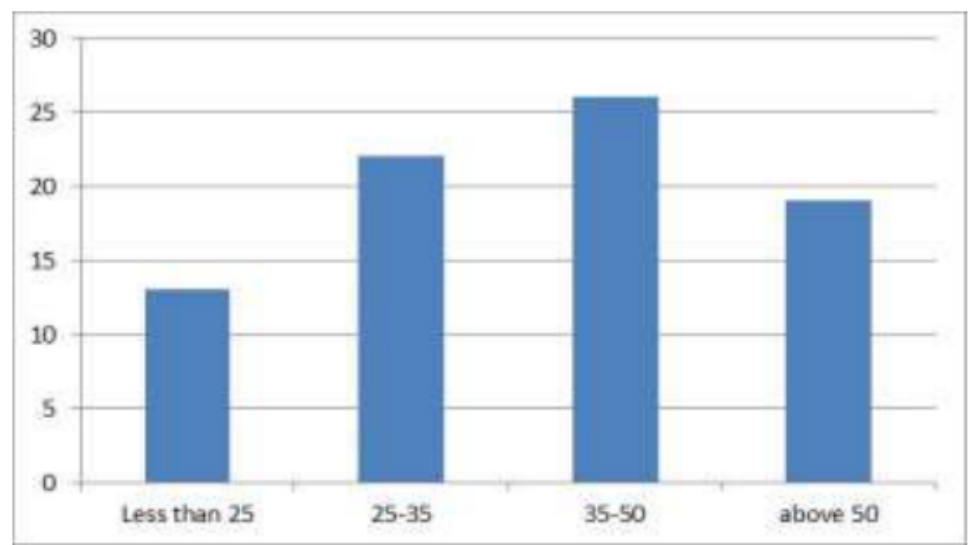

Figure 2 Respondents age profile

It is apparent in Figure 2 that the maximum number of respondents i.e. 26 counts out of total 80 were of age between 35-50 years and the least number i.e. 13 counts were of age less than 25 years. There are also a considerable number of respondents i.e. 19 counts above the age of 50 years resulting in a good mix of population in terms of age profile to collect responses from different age groups. 


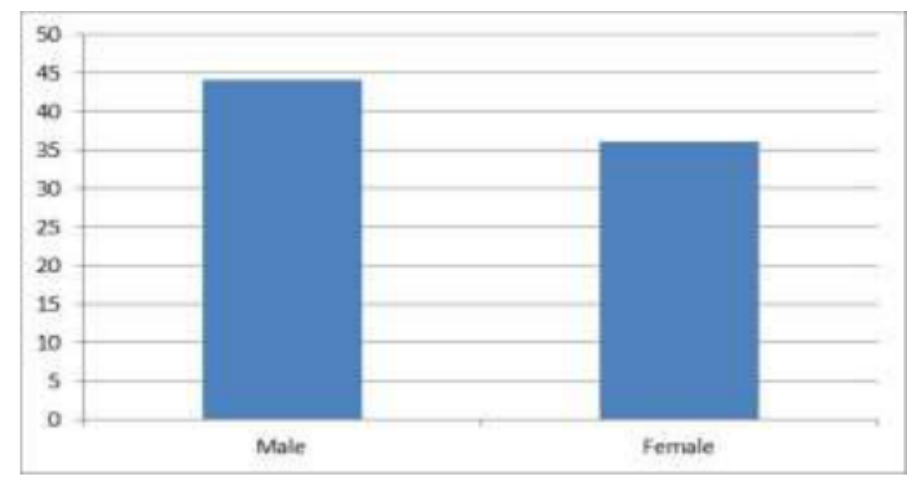

Figure 3 Respondents gender profile

As this particular study is related to the social issue associated with women and society as a whole so it was necessary to take opinion from both the genders. It is observed from Figure 3 that the responses were taken both from Male and Female respondents respectively counting male respondents more than female.

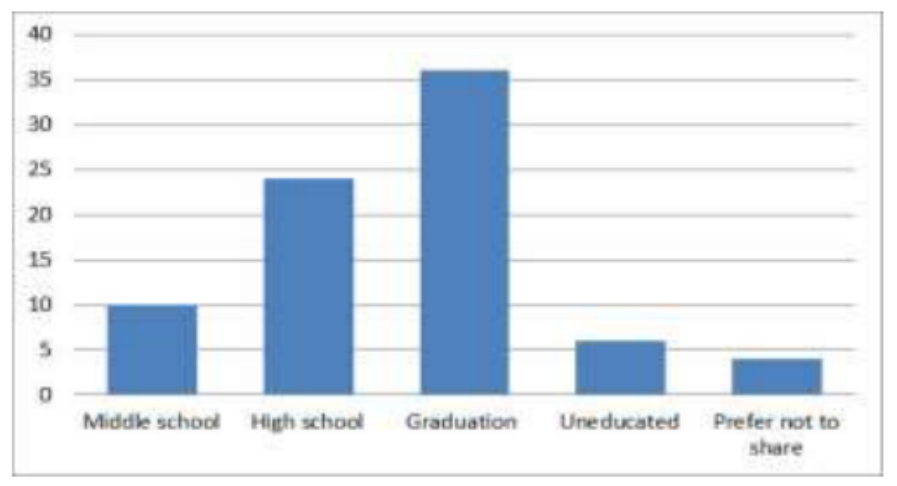

Figure 4 Respondents educational qualification

From Figure 4 it is evident that out of a total of 80 respondents, 36 were attaining graduate qualification followed by high school counts to 24 numbers. The number of uneducated respondents was as low as 6 . This data reveals that majority of the respondents were well qualified and have a reasonable understanding of the issue.

\subsection{Relative Importance Index}

The received responses from the respondents were summarized in an Excel data sheet and the data analyzed using SPSS software. Relative importance indices (RII) is performed to determine the priority of the significant factors and then followed by Reliability analysis performed to check the consistency of the data received.

$$
\text { Rii }=\frac{\sum_{\mathrm{r}=1}^{5} \mathrm{r}^{*} \mathrm{n}_{\mathrm{r}}}{5 \mathrm{~N}}
$$

Where, ' $r$ ' is the rating on a Likert scale (1-7) as for the impact of built environment attributes over crimes against women in NCT of Delhi, ' $n$ ' is the number of respondents providing a specific Likert scale rating $r$, ' $N$ ' is the aggregate number of respondents to a specific question [6]. The respondents were asked to rate the questions using a seven-point Likert Scale. 


\subsection{Reliability Cronbach's Alpha Value}

Further, Dependability analysis is required to check the consistency of the data, and Cronbach's alpha test was the best way to check the reliability of the data collected through the questionnaire [29]. The value of Cronbach's alpha for this study was 0.813, 0.714, 0.84, and 0.725 for IP Extension, Mayur Vihar-II, Shalimar Bagh, and Pitam Pura respectively which is considered to be good (table 1) [29]. The value of reliability analysis is the measure of the consistency and error-free of the data collected using a questionnaire survey. The value of reliability analysis varies from 0 to 1 and a value of more than 0.5 is considered good for study and to go ahead.

\subsection{Pilot Survey - Questionnaire Analysis}

Table 1 Perceived safety and Crime apprehension

\begin{tabular}{|c|c|c|c|c|c|}
\hline \multirow{2}{*}{$\begin{array}{l}\text { Que } \\
\text { s No. }\end{array}$} & \multirow{2}{*}{$\begin{array}{c}\text { Description } \\
\text { (Level of Delinquency) }\end{array}$} & \multicolumn{4}{|c|}{ Wards } \\
\hline & & $\begin{array}{c}\text { IP } \\
\text { Extensi } \\
\text { on }\end{array}$ & $\begin{array}{l}\text { Mayur } \\
\text { Vihar } \\
\text { II }\end{array}$ & $\begin{array}{l}\text { Pitam } \\
\text { Pura }\end{array}$ & $\begin{array}{c}\text { Shalima } \\
\text { r Bagh }\end{array}$ \\
\hline & & \multicolumn{4}{|c|}{ Cumulative Likert Scale Rating } \\
\hline 1. & How safe is this ward usually for women? & 6.4 & 6.5 & 1.6 & 1.7 \\
\hline 2. & $\begin{array}{l}\text { How unsafe you feel your ward is for } \\
\text { women (in case victimized) of following } \\
\text { crimes: }\end{array}$ & & & & \\
\hline 3.1 & Rape & 6.3 & 6.7 & 2.2 & 2.3 \\
\hline 3.2 & Robbery/snatching & 6.6 & 6.5 & 2.2 & 1.8 \\
\hline
\end{tabular}

Note: For perceived safety and crime apprehension a Likert scale of 1-7 has been used, where 1 is very safe, 2 is Safe, 3 is Some-what safe, 4 is Neutral, 5 is Some-what unsafe, 6 is Unsafe, and 7 is Very unsafe.

So higher is the value of Cumulative Likert Scale Rating more unsafe or perceived unsafe the ward by the local respondents.

Table 2 Built Environment Attributes

\begin{tabular}{|c|c|c|c|c|c|}
\hline \multirow{2}{*}{$\begin{array}{l}\text { Sr } \\
\dot{\mathrm{N}} \\
\mathbf{0} .\end{array}$} & \multirow{2}{*}{ (Attributes of Built Environment) } & $\begin{array}{c}\text { IP } \\
\text { Extension }\end{array}$ & $\begin{array}{c}\text { Mayur } \\
\text { Vihar-II }\end{array}$ & $\begin{array}{c}\text { Pitam } \\
\text { Pura }\end{array}$ & $\begin{array}{c}\text { Shalimar } \\
\text { Bagh }\end{array}$ \\
\hline & & \multicolumn{4}{|c|}{$\begin{array}{c}\text { Cumulative Likert Scale Rating Ward } \\
\text { wise }\end{array}$} \\
\hline 1 & Absence of street lights at night on roads and streets & 1.5 & 1.5 & 6.2 & 6.4 \\
\hline 2 & Presence of Abandoned neglected open recreational area & 1.6 & 1.4 & 6.4 & 6.3 \\
\hline 3 & Presence of unmaintained public open grounds & 1.7 & 1.5 & 6 & 6.2 \\
\hline 4 & Presence of Abandoned structures in un-inhabited areas & 1.8 & 1.5 & 5.9 & 6.3 \\
\hline 5 & $\begin{array}{l}\text { Poor maintenance of roads and parks leading to isolation } \\
\text { or minimal use of the space in the neighbourhood }\end{array}$ & 2 & 2.3 & 6 & 5.9 \\
\hline 6 & $\begin{array}{l}\text { Lack of installation of mechanical devices like CCTV } \\
\text { cameras for access control }\end{array}$ & 2 & 1.8 & 6 & 6.2 \\
\hline 7 & $\begin{array}{l}\text { High boundary walls on both sides of the pedestrian } \\
\text { street }\end{array}$ & 2 & 2.1 & 5.8 & 5.8 \\
\hline 8 & $\begin{array}{l}\text { Presence of diverse socio-economic population in } \\
\text { crowded public open areas }\end{array}$ & 1.4 & 1.9 & 6.3 & 6.4 \\
\hline 9 & $\begin{array}{l}\text { Lack of reporting of cases to attain humility/ self-respect } \\
\text { due to cultural settings. }\end{array}$ & 1.6 & 1.4 & 5.2 & 6.3 \\
\hline 10 & $\begin{array}{l}\text { Lack of reporting due to hectic/ uneconomical/ } \\
\text { untrustworthy/ lengthy/ women-unfriendly criminal } \\
\text { procedures in the court of law }\end{array}$ & 1.5 & 1.5 & 5.4 & 6.2 \\
\hline
\end{tabular}


Note: For physical infrastructure facilities, Land use, Up-keeping, CPTED strategies, neighbourhood characteristics, Sign of social disorder, Community characteristics, and Law and order, a Likert scale of 1-7 has been used, where 1 is strongly agreed, 2 is agree, 3 is somewhat agree, 4 neutral, 5 is somewhat disagree, 6 is disagree, and 7 is strongly disagree. So, higher is the value of cumulative Likert Scale Rating represent the adequate level of built environment facilities present and vice versa the lesser is the value represents the non-availability of basic desirable built environment facilities.

\subsection{Most Significant Factors}

The most significant built environment attributes having a vital impact over crimes against women in NCT of Delhi were observed from Table 3 are - Lack of reporting due to hectic/ uneconomical/ untrustworthy/ lengthy/ women-unfriendly criminal procedures in the court of law, Presence of diverse socio-economic population in crowded public open areas, Lack of Police Patrolling throughout the day, Presence of uncared urban utility like - water pumping rooms, electric sub-station, garbage disposal structure etc., and Absence of street lights at night on roads and streets in IP Extension, whereas Public drinking/consumption of alcohol/drugs in public areas, Lack of reporting of cases to attain humility/ self-respect due to cultural settings, Presence of Abandoned neglected open recreational area, Lack of Police Patrolling throughout the day, Presence of un-maintained public open grounds, Presence of Abandoned structures in uninhabited areas, Construction of toilets in isolated open areas and Presence of dark/hidden corners within the housing clusters due to faulty design in Mayur Vihar-II.

\section{CONCLUSIONS}

From table 2 it is very much clear that the respondents don't feel their wards safe for women as $91.7 \%$, and $92.4 \%$ in IP Extension and Mayur Vihar-II respectively feel unsafe for woman, and on the other hand $22.8 \%$ and $25 \%$ in Pitam Pura and Shalimar Bagh respectively feel unsafe for women in their wards. This clearly demonstrates the difference in perception of safety towards women between the people living in two different types of wards i.e. high crime rate wards (IP Extension and Mayur Vihar-II), and low crime rate ward (Pitam Pura and Shalimar Bagh). The majority of respondents also fear of the most inhuman crime against women; 'rape' score to $90 \%$, and $95.5 \%$ in IP Extension and MayurVihar-II respectively.

While looking at table 3 the following conclusions were drawn with respect to the built environment attributes responsible for the crime against women;

- Physical infrastructure: Absence of street lights at night on roads and streets, and Presence of uncared urban utility like - water pumping rooms, electric sub-station, garbage disposal structure etc. in both the wards (IP Extention and Mayur Vihar-II) scored lowest indicating to be the key factors contributing towards crime.

- Land use: Presence of Abandoned neglected open recreational areas, Presence of Abandoned structures in uninhabited areas and Presence of unmaintained public open grounds in both the wards (IP Extention and Mayur Vihar-II) are imperative among all.

- Up-keeping: Poor maintenance of roads and parks leading to isolation or minimal use of the space in the neighbourhood, and Unregulated disposal of garbage leading to segregated spaces in the neighbourhood in both the wards (IP Extention and Mayur ViharII) need attention and appropriate management.

- CPTED strategies: Lack of installation of mechanical devices like CCTV cameras for access control, and Lack of physical barriers like gates and barricades on roads in both wads (IP Extension and Mayur Vihar-II) to be examined and installed with resident's involvement at the grass root level. 
- Neighbourhood characteristics: High boundary walls on both sides of the Pedestrian Street, and Concealed/hidden corners in both wards (IP Extension and Mayur Vihar-II) acclaimed to be the important undesirable factors of the built environment.

- Social disorder: Illegal activities like gambling in public open spaces, and Presence of diverse socio-economic population in crowded public open areas in both wards (IP Extension and Mayur Vihar-II) are highly contributing towards crime against women.

- Community characteristics: Lack of reporting of cases to attain humility/ self-respect due to cultural settings, and Lack of involvement of women as stakeholders in community activities in both wards (IP Extension and Mayur Vihar-II) need to be dispensed at the social front with communal harmony.

- Law and order: Lack of reporting due to hectic/ uneconomical/ untrustworthy/ lengthy/ women-unfriendly criminal procedures in the court of law, and Lack of Police Patrolling throughout the day in both the wards (IP Extention and Mayur Vihar-II) represent constraints of utmost attention from law enforcing bodies for preventing criminal activities, especially against women.

This study clearly demonstrates that there is a very high significant difference in terms of the physical characteristics of the built environment and also in the social perception of the residents in both low and high crime areas. This study also validates that the wards had a higher rate of crime related to women is also not having sufficient desirable built environment availability. The results of this study reveal that the presence of augmented built environment factors in Shalimar Bagh and Pitam Pura supported very low crime incidents against women as compared to IP Extension and Mayur Vihar-II. This study also concludes that the crimes against women could be controlled and minimized by espousing ameliorate built environment in urban neighbourhoods.

\section{LIMITATIONS}

The study is conducted using a structured questionnaire survey and collection of primary data. The received responses are 80 in number, considered for this study is comparatively small to generalize the findings at a larger scale. The future scope of the study is to undertake a comprehensive study of all the attributes of built environment impacting the crime rates against women in NCT of Delhi through a structured questionnaire survey with a sample size of 450-500 to reduce the chances of error and to generalize the findings of the study.

\section{REFERENCES}

[1] C. Schnell, L. Grossman, and A. A. Braga, "The Routine Activities of Violent Crime Places: A Retrospective Case-Control Study of Crime Opportunities on Street Segments," J. Crim. Justice, no. September, pp. 1-14, 2018.

[2] M. Paydar, A. Kamani-Fard, and R. Etminani-Ghasrodashti, "Perceived Security of Women in Relation to Their Path Choice toward a Sustainable Neighbourhood in Santiago, Chile," Cities, vol. 60, pp. 289-300, 2017.

[3] G. Owusu, C. Wrigley-Asante, M. Oteng-Ababio, and A. Yaa Owusu, "Crime Prevention through Environmental Design (CPTED) and Built-Environmental Manifestations in Accra and Kumasi, Ghana," Crime Prev. Community Saf., vol. 17, no. 4, pp. 249-269, 2015.

[4] P. M. Cozens, G. Saville, and D. Hillier, "Crime Prevention through Environmental Design (CPTED): A Review and Modern Bibliography," Prop. Manag., vol. 23, no. 5, pp. 328-356, 2005.

[5] M. Hedayati Marzbali, A. Abdullah, J. Ignatius, and M. J. Maghsoodi Tilaki, "Examining the Effects of Crime Prevention Through Environmental Design (CPTED) on Residential Burglary," Int. J. Law, Crime Justice, vol. 46, pp. 86-102, 2016. 
[6] J. Prevatt, "Crime Prevention through Environmental Design (CPTED) and the Role of Facilities Planning in Force Protection," p. 134, 1998.

[7] P. Cozens and T. Love, "A Review and Current Status of Crime Prevention through Environmental Design (CPTED)," J. Plan. Lit., vol. 30, no. 4, pp. 393-412, 2015.

[8] D. W. Sohn, "Residential Crimes and Neighbourhood Built Environment: Assessing the Effectiveness of Crime Prevention through Environmental Design (CPTED)," Cities, vol. 52, pp. 86-93, 2016.

[9] V. Gibson and D. Johnson, "CPTED, But not as we Know it: Investigating the Conflict of Frameworks and Terminology in Crime Prevention through Environmental Design," Secur. J., vol. 29 , no. 2 , pp. 256-275, 2016.

[10] P. M. Cozens, "Sustainable Urban Development and Crime Prevention through Environmental Design for the British City. Towards an Effective Urban Environmentalism for the 21st Century," Cities, vol. 19, no. 2, pp. 129-137, 2002.

[11] S. Hekmat, K. Morgan, M. Soltani, and R. Gough, "Sensory Evaluation of Locally-Grown Fruit Purees and Inulin Fibre on Probiotic Yogurt in Mwanza, Tanzania and the Microbial Analysis of Probiotic Yogurt Fortified with Moringa Oleifera," J. Heal. Popul. Nutr., vol. 33, no. 1, pp. 60-67, 2015.

[12] G. Stummvoll, "Environmental Criminology and Crime Analysis," Crime Prev. Community Saf., vol. 11, no. 2, pp. 144-146, 2009.

[13] S. Dixit, "Analysing Enabling Factors Affecting the On-site Productivity in Indian Construction Industry," Period. Polytech. Archit., vol. 49, no. 2, pp. 185-193, Nov. 2018.

[14] S. Dixit and K. Saurabh, "Impact of Construction Productivity Attributes Over Construction Project Performance in Indian Construction Projects," Period. Polytech. Archit., Apr. 2019.

[15] S. Dixit, S. N. Mandal, J. V Thanikal, and K. Saurabh, "Evolution of Studies in Construction Productivity: A Systematic Literature Review (2006-2017),” Ain Shams Eng. J., 2019.

[16] R. H. Schneider and T. Kitchen, Crime prevention and the built environment. 2007.

[17] T. D. Crowe and D. L. Zahm, “\{Crime Prevention through Environmental Design\}," L. Dev., pp. 22-27, 1994.

[18] M. Hedayati Marzbali, A. Abdullah, N. A. Razak, and M. J. Maghsoodi Tilaki, "The Influence of Crime Prevention through Environmental Design on Victimisation and Fear of Crime," $J$. Environ. Psychol., vol. 32, no. 2, pp. 79-88, 2012.

[19] S. Foster, P. Hooper, M. Knuiman, H. Christian, F. Bull, and B. Giles-Corti, "Safe RESIDential Environments? A longitudinal analysis of the influence of crime-related safety on walking," Int. J. Behav. Nutr. Phys. Act., vol. 13, no. 1, pp. 1-9, 2016.

[20] O. Newman, Defensible space. Macmillan New York, 1972.

[21] O. Newman, Creating defensible space. Diane Publishing, 1996.

[22] P. Cozens and T. Van Der Linde, "Perceptions of Crime Prevention through Environmental Design (CPTED) at Australian Railway Stations," J. Public Transp., vol. 18, no. 4, pp. 73-92, 2015.

[23] J. S. Lee, S. Park, and S. Jung, "Effect of Crime Prevention Through Environmental Design (CPTED) Measures on Active Living and Fear of Crime," Sustain., vol. 8, no. 9, 2016.

[24] S. R. Md Sakip and A. Abdullah, "An Evaluation of Crime Prevention through Environmental Design (CPTED) Measures in a Gated Residential Area: A Pilot Survey," Asian J. Environ. Stud., vol. 3, no. 6, p. 21, 2018.

[25] S. R. Md Sakip and A. Abdullah, "An Evaluation of Crime Prevention through Environmental Design (CPTED) Measures in a Gated Residential Area: A Pilot Survey," Asian J. Environ. Stud., vol. 3, no. 6, p. 21, 2018.

[26] B. Yuen, "Safety and Dwelling in Singapore," Cities, vol. 21, no. 1, pp. 19-28, 2004.

[27] H. Koskela and R. Pain, "Revisiting Fear and Place: Women's Fear of Attack and the Built Environment," Geoforum, vol. 31, no. 2, pp. 269-280, 2000. 
[28] S. Foster and B. Giles-Corti, "The Built Environment, Neighborhood Crime and Constrained Physical Activity: An Exploration of Inconsistent Findings," Prev. Med. (Baltim)., vol. 47, no. 3, pp. 241-251, 2008.

[29] N. M. Gell, D. E. Rosenberg, J. Carlson, J. Kerr, and B. Belza, "Built Environment Attributes Related to GPS Measured Active Trips in Mid-Life and Older Adults with Mobility Disabilities," Disabil. Health J., vol. 8, no. 2, pp. 290-295, 2015.

[30] S. Foster, L. Wood, H. Christian, M. Knuiman, and B. Giles-Corti, "Planning Safer Suburbs: Do Changes in the Built Environment Influence Residents' Perceptions of Crime Risk?," Soc. Sci. Med., vol. 97, pp. 87-94, 2013.

[31] N. L. Bracy et al., "Is the Relationship between the Built Environment and Physical Activity Moderated by Perceptions of Crime and Safety?," Int. J. Behav. Nutr. Phys. Act., vol. 11, no. 1, pp. 1-13, 2014.

[32] N. Choucri and D. Goldsmith, "Lost in cyberspace: Harnessing the Internet, international relations, and global security," Bull. At. Sci., vol. 68, no. 2, pp. 70-77, 2012.

[33] M. M. Dupont, Véronique; Banda, Subhadra; Vaidya, Yashas ; Gowda, Shankare, "Unpacking Participation in Kathputli Colony," vol. xlIX, no. 24, pp. 39-47, 2014.

[34] R. Habibi, "The Institutionalization of Modern Middle Class Neighborhoods in 1940s Tehran - Case of Chaharsad Dastgah," Cities, vol. 60, pp. 37-49, 2017.

[35] A. N. Hewitt, E. Beauregard, M. A. Andresen, and P. L. Brantingham, "Identifying the Nature of Risky Places for Sexual Crime: The Applicability of Crime Pattern and Social Disorganization Theories in a Canadian Context," J. Crim. Justice, vol. 57, no. October 2017, pp. 35-46, 2018.

[36] S. Lodhia, "From 'Living Corpse' to India's Daughter: Exploring the Social, Political and Legal Landscape of the 2012 Delhi Gang Rape," Womens. Stud. Int. Forum, vol. 50, pp. 89$101,2015$.

[37] R. A. Slaughter, "The IT Revolution Reassessed Part One: Literature Review and Key issues," Futures, vol. 96, no. December 2017, pp. 115-123, 2018.

[38] J. Van Cauwenberg et al., "Differential Influences of Population Densification and Economic Growth on Europeans' Physical Activity and Sitting Time," Cities, vol. 82, no. October 2017, pp. 141-149, 2018.

[39] P. L. Laurence, “Jane Jacobs's Urban Ethics,” Cities, no. October 2017, pp. 0-1, 2018.

[40] W. Zhao and Y. Zou, "Un-gating the gated community: The spatial restructuring of a resettlement neighborhood in Nanjing," Cities, vol. 62, pp. 78-87, 2017.

[41] H. S. Geyer, H. C. Coetzee, D. Du Plessis, R. Donaldson, and P. Nijkamp, "Recent Business Transformation in Intermediate-sized Cities in South Africa," Habitat Int., vol. 35, no. 2, pp. 265-274, 2011.

[42] A. Timperio, J. Veitch, and A. Carver, "Safety in Numbers: Does Perceived Safety Mediate Associations between the Neighborhood Social Environment and Physical Activity among Women Living in Disadvantaged Neighborhoods?," Prev. Med. (Baltim)., vol. 74, pp. 49-54, 2015.

[43] J. Yin, X. J. Cao, X. Huang, and X. Cao, "Applying the IPA-Kano Model to Examine Environmental Correlates of Residential Satisfaction: A Case Study of Xi'an," Habitat Int., vol. 53, pp. 461-472, 2016.

[44] M. K. Shavarini, "The Role of Higher Education in the Life of a Young Iranian Woman," Womens. Stud. Int. Forum, vol. 29, no. 1, pp. 42-53, 2006.

[45] W. C. Ho and C. K. Cheung, "Social Sustainability for Mothers in Hong Kong's Low-Income Communities," Habitat Int., vol. 35, no. 4, pp. 529-536, 2011.

[46] J. Temelová and A. Slezáková, "The Changing Environment and Neighbourhood Satisfaction in Socialist High-Rise Panel Housing Estates: The Time-Comparative Perceptions of Elderly Residents in Prague," Cities, vol. 37, pp. 82-91, 2014.

[47] M. Garreton, "City Profile: Actually Existing Neoliberalism in Greater Santiago," Cities, vol. 65, pp. 32-50, 2017. 
[48] P. R. Anciaes, J. Nascimento, and S. Silva, "The Distribution of Walkability in an African City: Praia, Cabo Verde," Cities, vol. 67, no. April, pp. 9-20, 2017.

[49] D. R. Schaefer, "Youth Co-offending Networks: An Investigation of Social and Spatial Effects," Soc. Networks, vol. 34, no. 1, pp. 141-149, 2012.

[50] C. Makarewicz and J. Németh, "Are Multimodal Travelers more Satisfied with their Lives? A Study of Accessibility and Wellbeing in the Denver, Colorado Metropolitan area," Cities, vol. 74, no. December 2017, pp. 179-187, 2017.

[51] R. Pain, "Place, Social Relations and the Fear of Crime: A Review," Prog. Hum. Geogr., vol. 24, no. 3, pp. 365-387, 2000.

[52] M. Sliwa, "Master Plans and Urban Ecosystems: How the Poor Transform Land-Use from Rigid into Organic - A Case from Colombia," Habitat Int., vol. 66, pp. 1-12, 2017.

[53] Y. Wang, C. K. Chau, W. Y. Ng, and T. M. Leung, "A Review on the Effects of Physical Built Environment Attributes on Enhancing Walking and Cycling Activity Levels within Residential Neighborhoods," Cities, vol. 50, pp. 1-15, 2016.

[54] A. Todes and I. Turok, "Spatial inequalities and policies in South Africa: Place-based or people-centred?," Prog. Plann., vol. 123, pp. 1-31, 2018.

[55] K. Gurney, "Zombie Monument: Public art and Performing the Present," Cities, vol. 77, no. October 2017, pp. 33-38, 2018.

[56] I. Celino and S. Kotoulas, "Smart Cities," IEEE Internet Comput., vol. 17, no. 6, pp. 8-11, 2013.

[57] J. Dunagan, “Designer Governance," Futures, vol. 44, no. 9, pp. 832-844, 2012.

[58] A. Sinha and A. Kasdan, "Inserting Community Perspective Research into Public Housing Policy Discourse: The Right to the City Alliance's 'We Call These Projects Home," Cities, vol. 35, pp. 327-334, 2013.

[59] S. Bhattacharya and S. Rathi, "Reconceptualising Smart Cities: A Reference Framework for India," p. 80, 2015.

[60] M. Rouyer, "The Strauss-Kahn Affair and the Culture of Privacy: Mistreating and Misrepresenting Women in the French Public Sphere," Womens. Stud. Int. Forum, vol. 41, pp. 187-196, 2013.

[61] J. Salvatierra-Garrido and C. Pasquire, "Value Theory in Lean Construction," J. Financ. Manag. Prop. Constr., vol. 16, no. 1, pp. 8-18, 2011.

[62] L. Andersen, J. Gustat, and A. B. Becker, "The Relationship between the Social Environment and Lifestyle-Related Physical Activity in a Low-Income African American Inner-City Southern Neighborhood," J. Community Health, vol. 40, no. 5, pp. 967-974, 2015.

[63] F. L. Michael, Z. Z. Noor, and M. J. Figueroa, "Review of Urban Sustainability Indicators Assessment - Case Study between Asian Countries," Habitat Int., vol. 44, pp. 491-500, 2014.

[64] M. A. Ercan, "Developing Sustainable Communities in Historic Neighbourhoods of Istanbul," Tijdschr. voor Econ. en Soc. Geogr., vol. 102, no. 2, pp. 205-219, 2011.

[65] G. Helleman and F. Wassenberg, "The Renewal of what was Tomorrow's Idealistic City. Amsterdam's Bijlmermeer High-Rise," Cities, vol. 21, no. 1, pp. 3-17, 2004.

[66] E. G. Goetz, "The Audacity of HOPE VI: Discourse and the Dismantling of Public Housing," Cities, vol. 35, pp. 342-348, 2013.

[67] R. T. Massey, "Exploring Counter-Conduct in Upgraded Informal Settlements: The case of Women Residents in Makhaza and New Rest (Cape Town), South Africa," Habitat Int., vol. 44, pp. 290-296, 2014.

[68] Hanan M. Ahmad, The Effect of Barrier Buildings Gaps on Traffic Noise Attenuation in the Built Environment, International Journal of Civil Engineering and Technology,9(6), 2018, pp. 1280-1294

[69] Pratheek Sudhakaran, Jitendra Singh, Shailendra Kumar, Bhavesh Joshi, Bio-inspired Built Environments for Climate Change: Developing Strategies for Adaptation and Mitigation. International Journal of Civil Engineering and Technology, 8(9), 2017, pp. 955-965 